\title{
Effects of sterilization on dissolved organic carbon (DOC) composition and bacterial utilization of DOC from lakes
}

\author{
Martin G. I. Andersson¹, Núria Catalán ${ }^{1,2}$, Zeeshanur Rahman ${ }^{1,3}$, Lars J. Tranvik ${ }^{1}$, \\ Eva S. Lindström ${ }^{1, *}$ \\ ${ }^{1}$ Department of Ecology and Genetics/Limnology, Evolutionary Biology Centre, Uppsala University, Norbyv. 18D, \\ 75236 Uppsala, Sweden \\ ${ }^{2}$ ICRA, Catalan Institute of Water Research, Emili Grahit 101, 17003 Girona, Spain \\ ${ }^{3}$ Department of Botany, Zakir Husain Delhi College, University of Delhi, Delhi 110 002, India
}

\begin{abstract}
Sterilization of dissolved organic carbon (DOC) is an essential step in research on interactions between DOC and organisms, for example where the effect of different microbial communities on DOC is studied or vice versa. However, few studies have gone beyond acknowledging that sterilization of DOC influences its characteristics. Here, we aimed to provide further knowledge that enables scientists to better tailor their sterilization methods to their research question. To meet this aim, we conducted a sterilization experiment with DOC from 4 boreal lakes treated with 4 sterilization methods, i.e. 2 filtrations $(0.2 \mu \mathrm{m}, 0.1 \mu \mathrm{m})$ and 2 autoclaving approaches (single and double autoclaving with a single $\mathrm{pH}$ adjustment). Quantity and spectroscopic properties of DOC, before and after sterilization, were studied, and DOC was further tested as a substrate for bacterial growth. We found that the filtration methods better preserved the different DOC measures. In contrast, autoclaving caused major inconsistent shifts in both qualitative and quantitative measures of DOC, as well as an increase of the maximum abundance of bacteria in growth experiments. Nonetheless, there remains a trade-off between retaining the quality of DOC and achieving sterile conditions. Therefore, the sterilization method of choice should be guided by the scientific question at hand.
\end{abstract}

KEY WORDS: Microbial community $\cdot$ Filtration $\cdot$ Autoclave $\cdot$ DOM $\cdot$ EEMs $\cdot$ PARAFAC

\section{INTRODUCTION}

Bacteria play a key role in the cycling of dissolved organic carbon (DOC). Accordingly, there is considerable interest in experimental studies on the kinetics and compositional changes of DOC during degradation (Aluwihare \& Repeta 1999, Kujawinski et al. 2004), as well as on the role of bacterial community composition in DOC processing (Romaní et al. 2004, Peter et al. 2011, Calleja et al. 2013, Logue et al. 2016). In these experiments, it is often crucial to be able to independently modify

${ }^{*}$ Corresponding author: eva.lindstrom@ebc.uu.se both bacterial communities and DOC composition. Various filtration techniques to separate dissolved organic matter and bacteria from each other suffer from the overlap in size of colloidal organic matter and microorganisms (Lee \& Fuhrman 1987, Burd et al. 2000). The consequence of this overlap is that removing bacteria likely affects DOC quantity and quality (e.g. by reducing the amount of colloidal organic matter). Sterilization by autoclaving is both reliable and time efficient. However, autoclaving causes hydrolysis of organic matter, an effect that increases with increasing temperature (Papadim-

(C) The authors 2018. Open Access under Creative Commons by Attribution Licence. Use, distribution and reproduction are unrestricted. Authors and original publication must be credited. 
itriou 2010), and may have a multitude of effects on the chemistry and physical appearance of molecules and their aggregates. Experimental studies have also shown an enhancement of bacterial growth when cultivated in autoclaved medium (Jannasch 1969, Ammerman et al. 1984). Moreover, autoclaving of lake water frequently causes increased $\mathrm{pH}$ (Baho et al. 2012), which in turn affects bioavailability and utilization of DOC (Edling \& Tranvik 1996). Another possible method for sterilization is the use of antibiotics, but this method also has some apparent shortcomings. First, in complex environments, this method is unlikely to result in complete sterility even if antibiotics are added at high concentrations (Tranvik et al. 1993). Furthermore, the antibiotics themselves would become a part of the organic carbon pool, causing substantial increase in DOC (Tranvik et al. 1993). Finally, the antibiotics will persist in the medium, making it an unsuitable environment for antibiotic-susceptible microorganisms (Levy 2002).

The extent to which different methods used to separate dissolved organic matter and bacterial communities affect the organic matter pool has so far not been compared in a systematic way. The aim of our study was to evaluate the consequences of different sterilization methods on DOC bioavailability and quantity and on spectroscopic properties of lake water. Experiments were set up to address the following questions:

(1) How does the quality and quantity of DOC differ among different sterilization methods?

(2) Do the different sterilization methods affect DOC bioavailability differently?

(3) Are these effects consistent across DOC from different lakes?

We used water from 4 lakes differing greatly in DOC concentration and composition. These lake waters were sterilized by $0.2 \mu \mathrm{m}$ and $0.1 \mu \mathrm{m}$ filtration, autoclaving once and autoclaving twice with $\mathrm{pH}$ adjustment between the runs.

\section{MATERIALS AND METHODS}

\section{Sample collection and initial treatments}

Lake water was collected from 4 different lakes in east-central Sweden in the summer of 2014 (for details of these lakes, see Table S1 in the Supplement at www.int-res.com/articles/suppl/a082p199_supp. pdf). The lakes were chosen to represent boreal lakes with substantial differences in their DOC content.
After collection, the original lake water was immediately stored at $4{ }^{\circ} \mathrm{C}$, and sterilization treatments were carried out within $72 \mathrm{~h}$.

\section{Experimental setup}

Water from the 4 lakes (in triplicate) was exposed to 4 different sterilization treatments: $0.2 \mu \mathrm{m}$ filtration (0.2), $0.1 \mu \mathrm{m}$ filtration (0.1), autoclaving (AC) and double autoclaving (AC2). Both autoclaving treatments were adjusted for $\mathrm{pH}$ change with $\mathrm{HCl}$ $\left(1.2 \mathrm{~mol} \mathrm{l}^{-1}\right)$, after autoclaving (AC) or after the first autoclaving (AC2). The AC2 treatments were also left open to equilibrate with the atmosphere prior to the start of the second autoclaving. Autoclaving was performed at $121^{\circ} \mathrm{C}$ for $20 \mathrm{~min}(120 \mathrm{kPA})$. The $0.2 \mu \mathrm{m}$ filtration was done using Whatman ${ }^{\mathrm{TM}}$ Supor 200 Membrane $0.2 \mu \mathrm{m}$ pore size, while the $0.1 \mu \mathrm{m}$ was done with Whatman ${ }^{\mathrm{TM}}$ Supor 100 Membrane $0.1 \mu \mathrm{m}$ pore size. After sterilization, DOC quality and concentrations were investigated (see below for details). In addition, we investigated the bioavailability of the DOC in the following separate experiment. Untreated lake water $(20 \mathrm{ml})$ from the 4 lakes was inoculated into $180 \mathrm{ml}$ sterilized lake water of matching origin and kept in $250 \mathrm{ml}$ autoclaved screw cap glass bottles. The bottles were kept at $20^{\circ} \mathrm{C}$ in darkness for $6 \mathrm{~d}$. The bacterial abundance was monitored daily, while the DOC concentration was analyzed at the end of the experiment.

\section{Bacterial abundance}

Samples for bacterial counts were fixed with formaldehyde (final concentration $2 \%$ ), and cells were stained using Syto13 ${ }^{\circledR}$ (Molecular Probes, Invitrogen) for bacterial abundance according to del Giorgio et al. (1996). Cell counting of $50 \mu \mathrm{l}$ samples was performed with a flow cytometer equipped with a $488 \mathrm{~nm}$ blue solid state laser (Cyflow Space, Partec) and analyzed using Flowing Software version 2.51 (Perttu Terho, Centre for Biotechnology, Turku, Finland). The maximum bacterial abundance during the $6 \mathrm{~d}$ incubation period served as a measure of bacterial utilization of DOC in the different treatments.

\section{DOC analysis}

Water for DOC analysis was filtered through precombusted $\left(450^{\circ} \mathrm{C}, 4 \mathrm{~h}\right) \mathrm{GF} / \mathrm{F}$ Whatman ${ }^{\mathrm{TM}}$. DOC was 
quantified using a Total Organic Carbon Analyzer (Sievers 900) equipped with a membrane-based conductivity detector. Triplicate measurements were made of each sample. Eight measurements were excluded because of unreasonably low numbers $(<20 \%$ of the other 2 measurements), but each sample had at least 2 measurements. DOC was further characterized using spectroscopic methods. The absorbance spectra (200-800 $\mathrm{nm}$ ) were analyzed at $1 \mathrm{~nm}$ intervals with a Lambda 40 spectrophotometer (Perkin-Elmer). Samples were analyzed in a $1 \mathrm{~cm}$ quartz cuvette, and Milli-Q water was used as a blank. Fluorescence excitation-emission matrices (EEMs) were obtained using a spectrofluorometer (SPEX Fluoromax-4, Horiba Jobin Yvon). Excitation wavelengths ranged from 250 to $445 \mathrm{~nm}$ at intervals of $5 \mathrm{~nm}$, and the emission wavelengths from 300 to $600 \mathrm{~nm}$ at increments of $4 \mathrm{~nm}$. Sample EEMs were blank-subtracted using the EEM of Milli-Q water run the same day. The area underneath the water Raman scan was calculated and used to calibrate all sample intensities to Raman units. Correction factors supplied by the manufacturer were used to correct for instrument-specific biases. Spectra were corrected for the inner filter effect using the absorbance-based approach (McKnight et al. 2001, Kothawala et al. 2013). Corrections were applied using the FDOMcorr toolbox for MATLAB (Mathworks) following Murphy et al. (2010). The freshness or biological index (BIX) was calculated according to Huguet et al. (2009) and the humification index (HIX), an indicator of the degree of humification of the sample, was calculated as described by Ohno (2002).

\section{Parallel factor analysis}

Parallel factor analysis (PARAFAC) was used to identify the main components of the EEMs (Stedmon et al. 2003). The analysis used 54 samples (4 lakes and 4 treatments in triplicates, plus 4 original samples in triplicate, where 6 samples were lost in the process) and was performed in MATLAB using the DrEEM toolbox following Murphy et al. (2013). Accordingly, scatter peaks and outliers were removed, and each sample was normalized to its total fluorescence prior to fitting a PARAFAC model. The appropriate number of components was determined by visual inspection of the residual fluorescence (i.e. examining that the error residuals did not contain any apparent structure) and of the components' behavior as organic fluorophores (Lakowicz 2006, Murphy et al. 2013). The model was then validated by split-half analysis and random initialization with 10 iterations. We interpreted the components based on their fluorescence maxima, compared with the matched emission and excitation spectra in the OpenFluor database (https://openfluor.lablicate.com/), corresponding to components previously identified in natural aquatic systems. The results of the PARAFAC model were queried (Tucker's congruence coefficient $=95 \%$ ) in the OpenFluor database in order to search for quantitative matches with previously published and validated PARAFAC models (Murphy et al. 2014). We report the PARAFAC components (C1-C5, see Table 1) both in Raman units and their relative intensity (i.e. \% $\mathrm{C} 1=\mathrm{C} 1 /(\mathrm{C} 1+$ $\mathrm{C} 2+\mathrm{C} 3+\mathrm{C} 4+\mathrm{C} 5)$ ) in order to be able to compare changes in fluorescence intensities among different sterilization methods minimizing the effect of the DOC concentration. Test of DOC components was performed on the original values of the PARAFAC analysis unless otherwise specified. To further visualize differences across EEMs after the sterilization treatments, we also calculated the proportional change in intensity in relation to the original sample, in all cases using the mean EEM of the 3 replicates. Finally, the proportional change in intensity for each treatment in relation to the original sample was calculated, to assess the changes in PARAFAC components.

\section{Statistics}

Effects of treatments on maximum bacterial abundance and DOC concentration were tested with type 3, 2-way ANOVAs ('Anova' function, 'car' package in R) followed by a post hoc general contrast Tukey test on the least squares means of the factor levels ('lsmeans' and 'contrast' functions in 'emmeans' package in R). Most measured parameters showed no Gaussian distribution, which was dealt with by ranking the data before the ANOVAs ('rank', 'base' package). Correlation analyses were run as 2-sided Spearman rank correlations in R ('cor.test'). The effects of lakes and treatments on the PARAFAC components were tested with permutational MANOVAs (PERMANOVAs) using $z$-score transformed values ('scale', 'base' package in R) that was converted into a Euclidean distance matrix ('adonis' function, 'vegan' package in R).

In order to explore possible relationships between the growth of bacteria in the bioavailability experiment and the characteristics of the DOC, we used partial least squares regression (PLS). PLS is a mul- 
tiple regression method that is comparatively insensitive towards dependency of explanatory variables (co-correlation) as well as deviations from normality. In our analysis, explanatory variables ( $x$-variables) were the fluorescence components, fluorescent DOM, BIX and HIX. Skewed variables were transformed (function scale, default setting, 'base' package in R). The dependent variable (y) was the maximum abundance of bacteria. The outcome of the PLS is given by $\mathrm{R}^{2} x, \mathrm{R}^{2} y$, and $\mathrm{Q}^{2}$ values. The $\mathrm{R}^{2} \boldsymbol{x}$ and $\mathrm{R}^{2} y$ are similar to the $\mathrm{R}^{2}$ in linear regression, i.e. an estimate of how much of the variance in $y$ and $x$ is explained by the components. $Q^{2}$ is indicative of the predictive power of the model, where a large dissimilarity between the $\mathrm{Q}^{2}$ and $\mathrm{R}^{2} y$ values is indicative of overfitting of the model (Eriksson et al. 2006). We evaluated the influence of each $x$ variable by using variable importance on the projection (VIP) scores (Eriksson et al. 2006). Highly influencing variables were considered those having VIP $>1$, while variables with moderate influence were $0.8<$ VIP $<1$. We carried out PLS models in XL-STATS software (XL-STATS 19.4.46593, AddinsoftSRAL).

\section{RESULTS}

Sterilization method affected maximum bacterial abundance, where the highest numbers were in the $\mathrm{AC}$ treatments and the lowest in the $0.1 \mu \mathrm{m}$ filtration treatment (Fig. 1A) (2-way ANOVA, lake p > 0.05,
$F=1.7, \mathrm{df}=3$; sterilization $\mathrm{p}<0.001, F=10.47, \mathrm{df}=3$; interaction $\mathrm{p}<0.01, F=3.54$, df $=9$ ). The significant interaction term showed that results of sterilization were slightly different among lakes. Maximum abundance was used, since several cultures showed a decline in abundance towards the end of the growth experiment (Fig. S1 in the Supplement).

Sterilization method was of less significance than lake for DOC concentration, but both factors were significant (Fig. 1B) (2-way ANOVA: lake p $<0.001$, $F=78.27, \mathrm{df}=3$; sterilization $\mathrm{p}<0.01, F=4.6, \mathrm{df}=3$; interaction $\mathrm{p}=0.01, F=2.96, \mathrm{df}=9$ ). Post hoc analysis of the effect of sterilization treatment showed that the 0.1 treatment had significantly lower DOC than all other treatments (Fig. 1B). There were also some differences among other treatments, but with no apparent trend. The significant interaction term also shows that there were differences among lakes in response to the sterilization treatments. Most strikingly, in Lake Lötsjön, DOC concentrations appeared to have increased from $9.6 \mathrm{mg} \mathrm{l}^{-1}$ in the original sample to 16.3 and $18.0 \mathrm{mg} \mathrm{l}^{-1}$ in $\mathrm{AC}$ and $\mathrm{AC} 2$, respectively. Rerunning the ANOVAs of DOC while excluding the values of Lake Lötsjön showed that lake and treatment and their interaction still had significant effects on DOC concentration (2-way ANOVA: lake p < 0.001, $F=143.0$, df $=2$; sterilization $\mathrm{p}<0.001, F=$ 11.9, df $=3$; interaction $\mathrm{p}<0.001, F=6.85$, df $=6$ ). The post hoc analysis revealed that the 0.1 filtration treatment was significantly different from all other treatments ( $p<0.05$, data not shown). A correlation analysis between DOC concentration and maximum
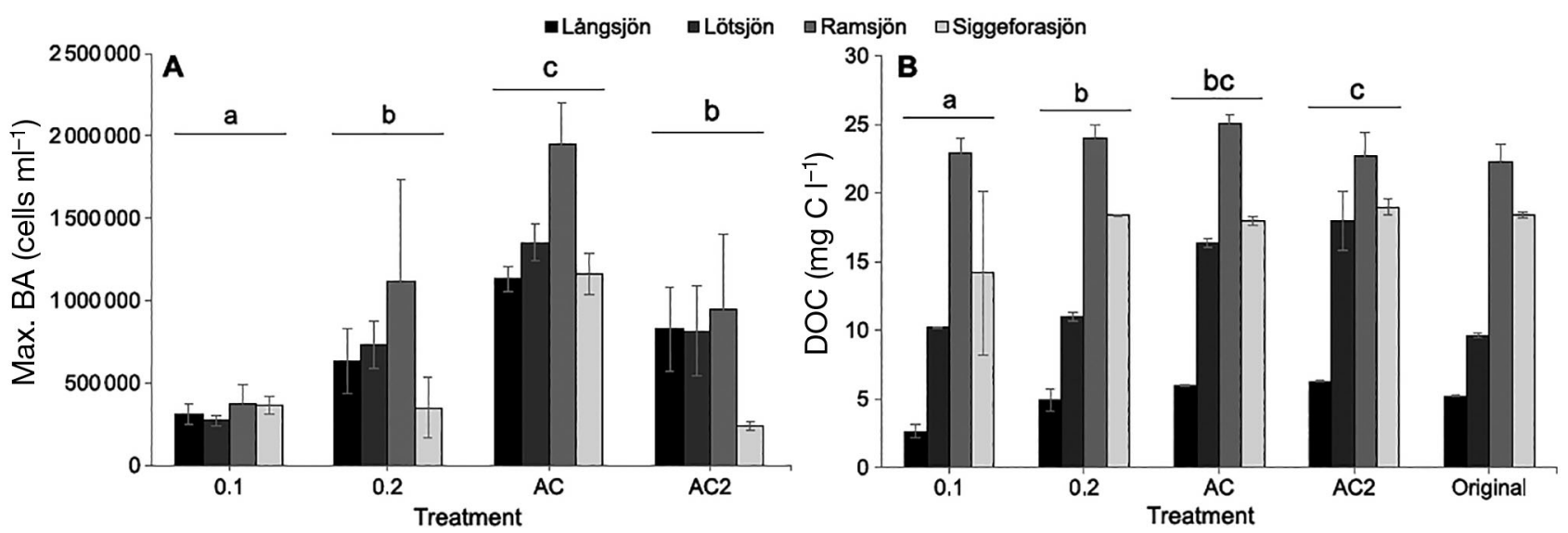

Fig. 1. Effects of sterilization on (A) maximum bacterial abundance (BA, cells $\mathrm{ml}^{-1}$ ) and (B) dissolved organic carbon (DOC) concentration $\left(\mathrm{mg} \mathrm{C}^{-1}\right.$ ). The bars are average values of triplicates and error bars show SD; error bars for original (i.e. untreated) water samples are for technical replicates. Different letters above bars represent groups that were significantly different from each other based on post hoc tests. Note that the original samples were not included in the ANOVA, and thus no post hoc results are shown. Treatments are as follows; 0.1: $0.1 \mu \mathrm{m}$ filtration; 0.2: $0.2 \mu \mathrm{m}$ filtration; AC: single autoclaving; AC2: double autoclaving 

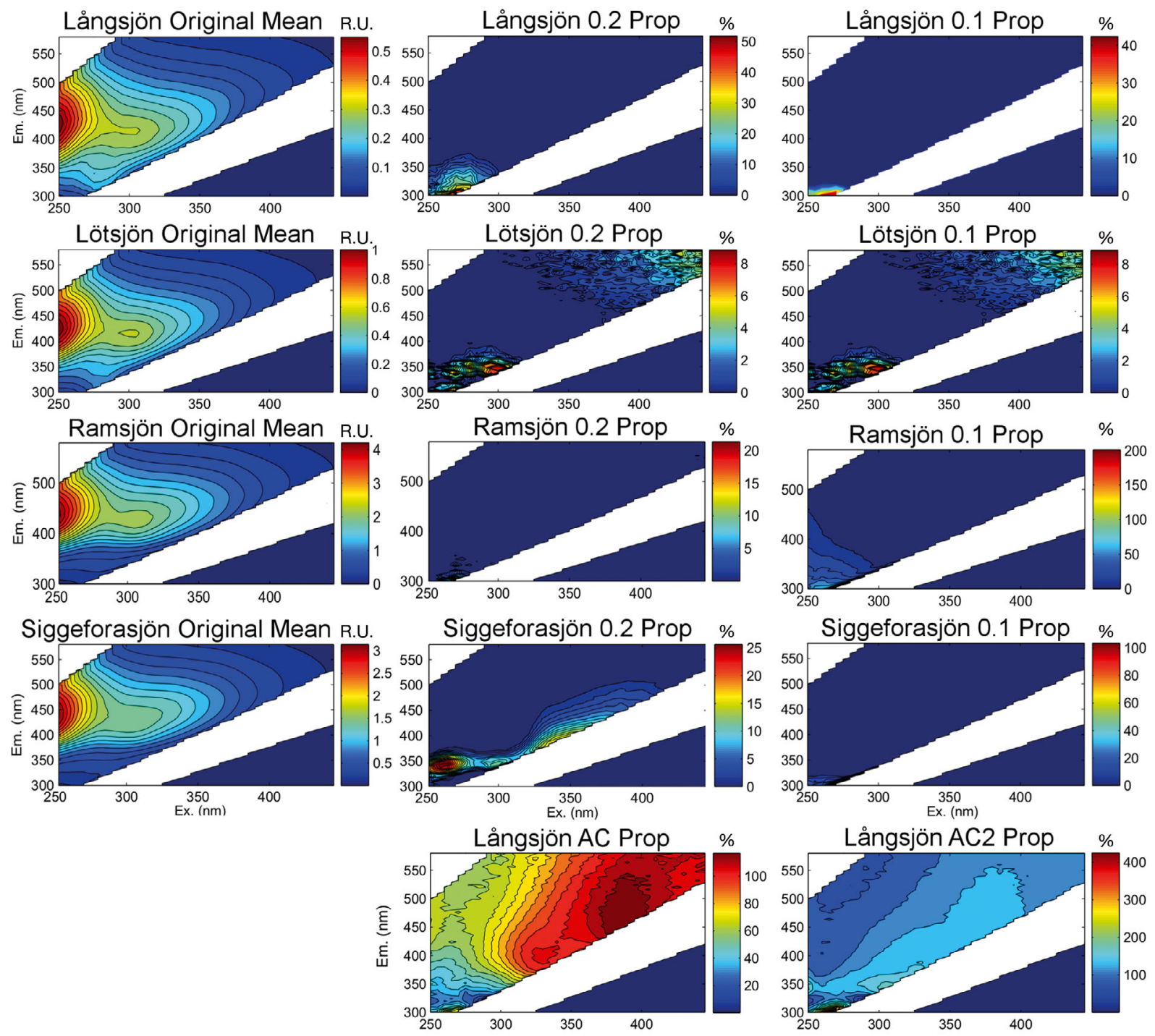

Fig. 2. Excitation-emission matrices showing the original lake waters and the proportional changes following each treatment. The columns represent treatments, where graphs in the leftmost column show the original dissolved organic matter, and the other panels show the proportional changes from the original water after each treatment; rows are different lakes. All data presented are the means of 3 replicates (in the case of the original water replicate measurements) or replicate treatments (in the other cases). The color scale bars are in Raman units (RU) for the original samples and in \% for the relative changes (note that negative values were set to 0 and differences in the values of the color scale for each graph [maximum in red] were adjusted to highest value in each case)
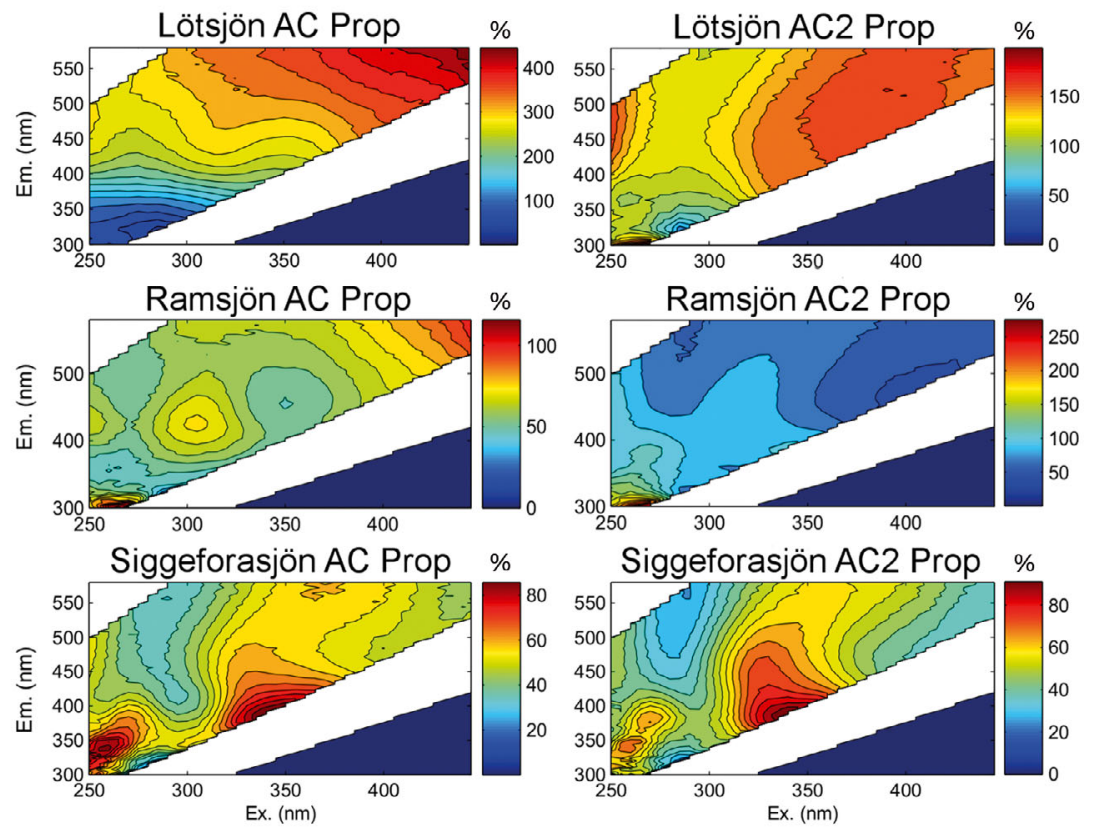
Table 1. Description and excitation and emission wavelength maximum (secondary maxima in brackets) of the identified parallel factor (PARAFAC) components (further details are provided in Fig. S3 in the Supplement)

\begin{tabular}{|c|c|c|}
\hline $\begin{array}{l}\text { Compo- } \\
\text { nent }\end{array}$ & $-\lambda_{\mathrm{EX}} / \lambda_{\mathrm{EM}}$ & Classification and description \\
\hline $\mathrm{C} 1$ & $250(330) / 444$ & Humic-like. Previously identified in boreal systems ${ }^{\mathrm{a}, \mathrm{b}}$ and related to terrestrial sources ${ }^{\mathrm{c}}$ \\
\hline $\mathrm{C} 2$ & $275(390) / 500$ & $\begin{array}{l}\text { Humic-like, ubiquitous }{ }^{\mathrm{d}} \text {. Related to large molecular size aromatic hydrophobic } \\
\text { compounds }^{\mathrm{e}}{ }_{i} \text { reactive character and fast loss rates in nature }{ }^{\mathrm{b}}\end{array}$ \\
\hline $\mathrm{C} 3$ & $250 / 444$ & $\begin{array}{l}\text { Humic-like. Described as peak } \mathrm{A}^{\mathrm{f}} \text { and related to terrestrially derived materials, } \\
\text { intermediate persistence in boreal systems } \mathrm{s}^{\mathrm{b}}\end{array}$ \\
\hline $\mathrm{C} 4$ & $300 / 420$ & $\begin{array}{l}\text { Humic-like, microbially derived. Related to peak } \mathrm{M}^{\mathrm{f}} \text {, likely the intermediate result of } \\
\text { degradation processes }{ }^{\mathrm{a}, \mathrm{b}}\end{array}$ \\
\hline C5 & $280(250) / 388$ & Protein-like. Related to microbial activity and/or aquatic production ${ }^{g, h}$ \\
\hline
\end{tabular}

bacterial abundance was not significant (Spearman rank correlation analysis; $\mathrm{p}>0.05$. $\mathrm{rho}=0.20, \mathrm{n}=48$ ).

The overall shape of the EEMs changed in response to each sterilization treatment (Fig. 2; Fig. S2 in the Supplement), especially in the auto- claving treatments in all lakes. PARAFAC modeling of EEM spectra from all 54 samples resulting from the experiment revealed 5 independent components (C1-C5; Table 1; Fig. S3 in the Supplement). Components $\mathrm{C} 1-\mathrm{C} 4$ correspond to humic-like materials,

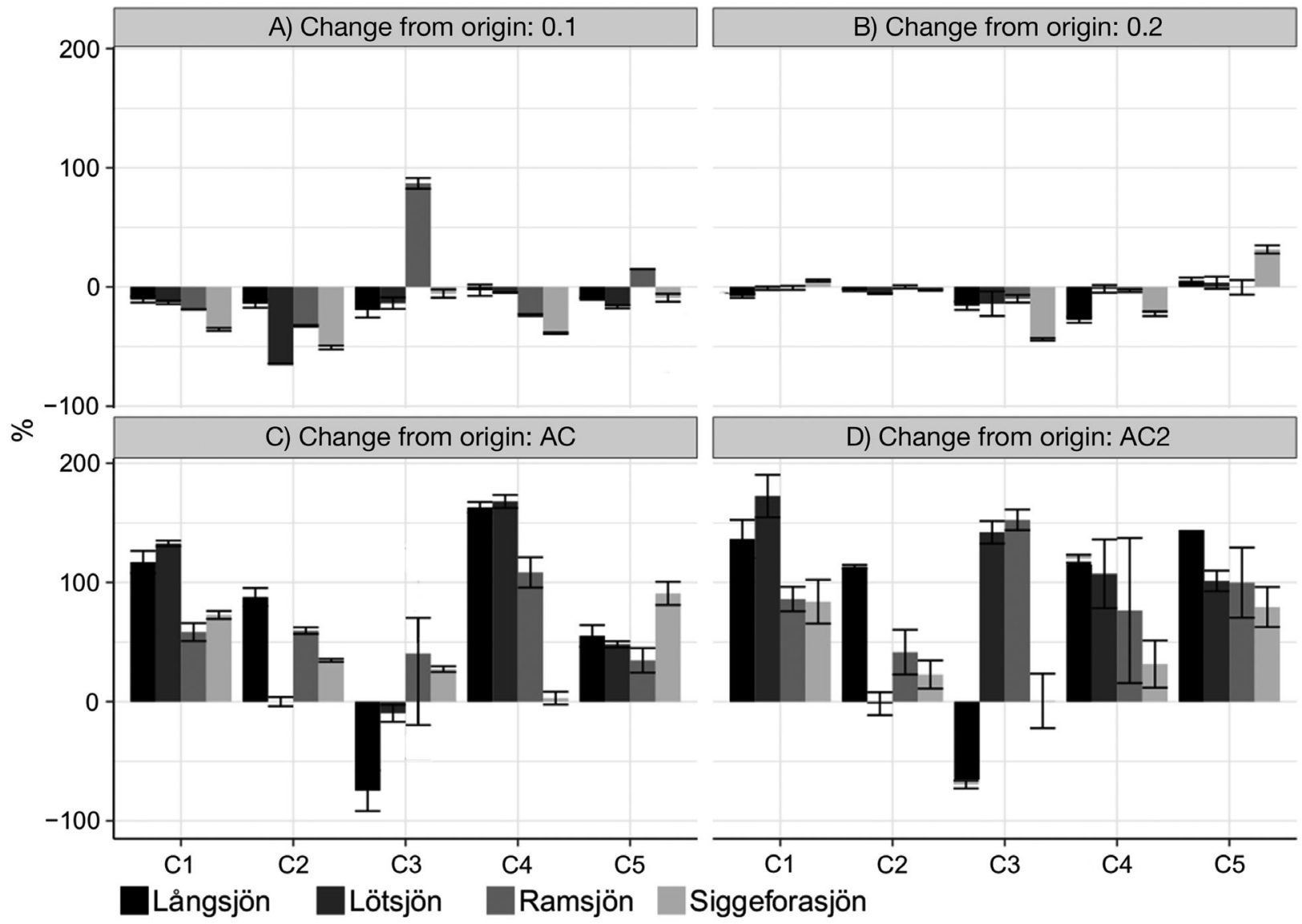

Fig. 3. Effect of sterilization on the percentage of change of the parallel factor (PARAFAC) components (C1-C5, see Table 1) in relation to the original lake water in (A) $0.1 \mu \mathrm{m}$ filtration, (B) $0.2 \mu \mathrm{m}$ filtration, (C) single autoclaving (AC) and (D) double autoclaving (AC2). Data are averages of replicates, with error bars representing the SD 
and component C5 to protein-like fluorescence. The components were significantly affected by both sterilization methods and lake and their interaction (PERMANOVA, Euclidean distance, permutations = 1000, sterilization; $\mathrm{p}<0.001, F=56.03$, df $=3$; lake $\mathrm{p}<0.001, F=159.5$, df $=3$; interaction, $F=7.3, \mathrm{p}<$ 0.001 , df $=12$ ). The relative intensity of the components followed a similar pattern as the raw components (PERMANOVA, Euclidean distance, permutations $=1000$, sterilization; $\mathrm{p}<0.001, F=30.5$, df $=3$; lake $\mathrm{p}<0.001, F=45.7, \mathrm{df}=3$; interaction, $F=6.3$, $\mathrm{p}<0.001$, df $=12$ ). There was an overall relative increase (in relation to the original waters) in the PARAFAC components as a response to both autoclaving treatments (Fig. 3). The greatest changes occurred at longer emission and excitation wavelengths, the region that encompasses component C1 (Table 1, Fig. 2; Fig. S4 in the Supplement), associated with humic substances.

The impact of the autoclaving treatments on the components varied greatly among lakes. In the clearwater lakes Långsjön and Lötsjön, the intensity of most components increased after autoclaving to a greater extent than in the humic lakes. Further, different regions of the EEMs were affected differently (Figs. 2 \& 3). The effects of autoclaving on C3 presented the strongest dependency on the origin of a sample, as this component showed both great increase and decrease in relative intensity within the same sterilization treatment (Fig. 3). The 0.1 filter had a stronger impact on components relative to the 0.2 filter, particularly on $\mathrm{C} 1$ and C2. Overall, filter treatments decreased the fluorescence of the components relative to the original samples (Fig. 3). However, these effects were relatively minor and typically well below $25 \%$ proportional variation in signal strength compared to the untreated lake water (Figs. 2 \& 3). Moreover, these changes affected localized areas of the EEMs, generally towards the shortest excitation and emission wavelengths. The impact of filtration was more consistent across sites and components than the effects of autoclaving. However, changes were slightly more pronounced in the humic lake Siggeforasjön compared to the other lakes.

We found only weak positive relationships between components and the maximum bacterial abundance, being significant in only 2 cases (Spearman rank correlation, component $\mathrm{C} 2$; $\mathrm{p}<0.05, \mathrm{r}^{2}=$ 0.36; component C5; $\left.\mathrm{p}<0.05, \mathrm{r}^{2}=0.3\right)$. The PLS model explained $31.8 \%$ (component C1) and 10.4\% (component $\mathrm{C} 2$ ) of the observed variation in maximum bacterial abundance (full model: $\mathrm{R}^{2} \mathrm{y}$ : 0.422, $\mathrm{R}^{2} \mathrm{X}$ : 0.791, $\mathrm{Q}^{2}$ : 0.318). Fluorescence components $\mathrm{C} 2$ and C4 had the highest VIP values (>1), with C2 being the most influential variable correlated positively with bacterial abundance (Fig. S5, Table S2 in the Supplement; PLS, XL-STATS).

\section{DISCUSSION}

This experiment demonstrates that the properties of DOC and its interactions with microorganisms are sensitive to all tested sterilization methods. We found that autoclaving had strong effects on DOC properties, and that these effects were difficult to predict in the sense that they differed among waters and autoclaving treatments.

Bacterial abundance was significantly enhanced in the single autoclaving (AC) treatment, compared to the other treatments. However, this did not seem to be because of increased DOC concentration, since no significant relationship between DOC concentration and maximum bacterial abundance was found. DOC composition, however, changed much more in the autoclaving treatments than in the filtration treatments. We also found a statistical relationship between maximum bacterial abundance and PARAFAC components, particularly C4 and C2, indicating that change in DOC composition facilitated bacterial growth. The effect of autoclaving on DOC composition could be caused by changes in DOC compounds due to hydrolysis and denaturation of various compounds and colloids during autoclaving (Dill \& Shortie 1991, Druart \& De Wulf 1993), changing the bioavailability. Plausible scenarios for the enhanced growth due to autoclaving are addition of fresh organic material through the lysis of cells (Middelboe \& Jørgensen 2006), destruction of viral particles (Espy et al. 2002) or the release of inorganic nutrients from recalcitrant DOC (Berns et al. 2008). The statistical relationship between bacterial abundance and DOC composition was relatively weak. Note further that there was a strong difference in bacterial abundance between the 2 autoclaving treatments despite them having similar apparent DOC composition, thus questioning the causation behind the correlation of growth and components.

Regardless of causation, increases in growth rates following autoclaving of natural water have been observed previously (Jannasch 1969, Ammerman et al. 1984). Ammerman et al. (1984) further displayed that the effect of autoclaving on growth rate depended on whether the water was pre-filtered, indicating that particles, such as lysed algae, con- 
tributed to this effect. In our study, increases in growth rate occurred across all lakes tested, demonstrating that this aspect of autoclaving is consistent (Fig. 1A). From a chemical perspective, the exact consequences of autoclaving DOC are highly complex. A well-studied example of this is denaturation of proteins. The effect of heat-induced denaturation varies from protein to protein, depending on the composition and folding of the protein as well as the temperature, exposure time, $\mathrm{pH}$ condition, etc. (Dill \& Shortie 1991). Given the chemical diversity of DOC, it is then fair to assume that the specific chemical reactions will be lake dependent and with our current knowledge, largely unpredictable. The EEMs also provide support for this, as lakes could have either very distinct or highly similar patterns between the 2 autoclaving treatments (e.g. Långsjön \& Siggeforasjön; Fig. 2). The unpredictability of autoclaving is further demonstrated by the fluorescence component $\mathrm{C} 3$, associated with low molecular weight humic substances (Ishii \& Boyer 2012), where intensity showed increases, decreases, and no changes following autoclaving, depending on the lake tested (Fig. 3). An unexpected result of the experiment was the observed increase in DOC concentration following autoclaving in Lake Lötsjön (Fig. 1); we have no obvious explanation for this result. Acknowledging that this result could be because of contamination, the ANOVA with DOC was run with and without Lötsjön samples, and the sterilization effect remained significant.

The 0.2 filtration caused only minor alterations of the fluorescent components while the 0.1 caused a decrease in $\mathrm{C} 1$ and $\mathrm{C} 2$ (Fig. 3). $\mathrm{C} 1$ and $\mathrm{C} 2$ are related to humic, aromatic substances (Table 1). These are frequently hydrophobic and prone to form supramolecular structures (Kellerman 2015) and build up colloids (Tranvik \& von Wachenfeldt 2009) and thus could be removed by filtration. In any case, the patterns found for both filtration treatments are more consistent than for autoclaving, and therefore the effect on DOC of these sterilizations seems to be more predictable in its outcome.

\section{CONCLUSION AND RECOMMENDATIONS}

Filtration had the least and most consistent impact on DOC concentration and composition in most measured parameters. Thus, if aiming to produce an experimental source of DOC representative of natural DOC, filtration should be the method of choice. On the other hand, to successfully achieve sterility by filtration is challenging, especially $0.2 \mu \mathrm{m}$ filtration (Vybiral et al. 1999, Sundaram et al. 2001). In certain experimental designs, having a few cells surviving the sterilization rapidly followed by an inoculation of cell numbers several magnitudes higher could be a pragmatic solution if absolute sterility cannot be achieved. An alternative method not tested here but that has been used in contamination-sensitive studies is the $0.2 \mu \mathrm{m}$ triple filtration (e.g. Garcia et al. 2014), reducing the likeliness of cells in the filtrate. In studies with large volumes that require long-term sterility, reliability and efficiency can be essential, potentially making autoclaving preferable. Additionally, it is important to note that even if autoclaving changed DOC in an unpredictable manner, it did not cause a convergence of the DOC pool of the different lakes (Fig. S4). Hence, autoclaving does preserve the diversity of conditions that different lake waters represent, although not identical to the initial conditions. Thus, it is still possible to use autoclaved lake water for experimental designs that require sterility and a variety of different complex sources of DOC. Nonetheless, there is a trade-off between retaining the natural quality of DOC and achieving sterile conditions. The method of sterilization, and hence the position to be taken in this trade-off, should be guided by the scientific question at hand.

Acknowledgements. Z.R. received funding from the Erasmus Mundus Expert III scholarship for a $\mathrm{PhD}$ exchange program during the study period. N.C. held a Beatriu de Pinos grant (AGAUR-BP2015-00215) from the Catalan Government.

\section{LITERATURE CITED}

Aluwihare LI, Repeta DJ (1999) A comparison of the chemical characteristics of oceanic DOM and extracellular DOM produced by marine algae. Mar Ecol Prog Ser 186: 105-117

Ammerman JW, Fuhrman JA, Hagström Å, Azam F (1984) Bacterioplankton growth in seawater: I. Growth kinetics and cellular characteristics in seawater cultures. Mar Ecol Prog Ser 18:31-39

Baho DL, Peter H, Tranvik LJ (2012) Resistance and resilience of microbial communities - temporal and spatial insurance against perturbations. Environ Microbiol 14: 2283-2292

Berns AE, Philipp H, Narres HD, Burauel P, Vereecken H, Tappe W (2008) Effect of gamma-sterilization and autoclaving on soil organic matter structure as studied by solid state NMR, UV and fluorescence spectroscopy. Eur J Soil Sci 59:540-550

Burd AB, Moran S, Jackson GA (2000) A coupled adsorption-aggregation model of the $\mathrm{POC} /{ }^{234} \mathrm{Th}$ ratio of marine particles. Deep-Sea Res I 47:103-120

* Calleja ML, Batista F, Peacock M, Kudela R, McCarthy MD (2013) Changes in compound specific $\delta^{15} \mathrm{~N}$ amino acid 
signatures and $\mathrm{d} / \mathrm{l}$ ratios in marine dissolved organic matter induced by heterotrophic bacterial reworking. Mar Chem 149:32-44

Coble PG (1996) Characterization of marine and terrestrial DOM in seawater using excitation-emission matrix spectroscopy. Mar Chem 51:325-346

del Giorgio PA, Bird DF, Prairie YT, Planas D (1996) Flow cytometric determination of bacterial abundance in lake plankton with the green nucleic acid stain SYTO 13. Limnol Oceanogr 41:783-789

Dill KA, Shortie D (1991) Denaturated states of proteins. Annu Rev Biochem 60:795-825

Druart P, De Wulf O (1993) Activated charcoal catalyses sucrose hydrolysis during autoclaving. Plant Cell Tissue Organ Cult 32:97-99

Edling $\mathrm{H}$, Tranvik L (1996) Effects of $\mathrm{pH}$ on $\beta$-glucosidase activity and availability of DOC to bacteria in lakes. Arch Hydrobiol 48:123-132

Eriksson L, Johansson E, Kettaneh-Wold N, Trygg J, Wikstr C, Wold S (2006) Multi-and megavariate data analysis: part I: basic principles and applications. 2nd revised and enlarged edn. Umetrics, Umeå

Espy MJ, Uhl JR, Sloan LM, Rosenblatt JE, Cockerill FR III, Smith TF (2002) Detection of vaccinia virus, herpes simplex virus, varicella-zoster virus, and Bacillus anthracis DNA by LightCycler polymerase chain reaction after autoclaving: implications for biosafety of bioterrorism agents. Mayo Clin Proc 77:624-628

Garcia SL, McMahon KD, Grossart HP, Warnecke F (2014) Successful enrichment of the ubiquitous freshwater acI Actinobacteria. Environ Microbiol Rep 6:21-27

* Graeber D, Gelbrecht J, Pusch MT, Anlanger C, von Schiller D (2012) Agriculture has changed the amount and composition of dissolved organic matter in Central European headwater streams. Sci Total Environ 438:435-446

Huguet A, Vacher L, Relexans S, Saubusse S, Froidefond JM, Parlanti E (2009) Organic geochemistry properties of fluorescent dissolved organic matter in the Gironde Estuary. Org Geochem 40:706-719

* Ishii SKL, Boyer TH (2012) Behavior of reoccurring PARAFAC components in fluorescent dissolved organic matter in natural and engineered systems. Environ Sci Technol 46:2006-2017

Jannasch HW (1969) Estimations of bacterial growth rates in natural waters. J Bacteriol 99:156-160

Kellerman AM (2015) Molecular-level dissolved organic matter dynamics in lakes: constraints on reactivity and persistence. PhD dissertation, Uppsala University

Kothawala DN, Murphy KR, Stedmon CA, Weyhenmeyer GA, Tranvik LJ (2013) Inner filter correction of dissolved organic matter fluorescence. Limnol Oceanogr Methods 11:616-630

Kothawala DN, Stedmon CA, Müller RA, Weyhenmeyer GA, Köhler SJ, Tranvik LJ (2014) Controls of dissolved organic matter quality: evidence from a large-scale boreal lake survey. Glob Change Biol 20:1101-1114

Kothawala DN, Ji X, Laudon H, Ågren AM, Futter MN, Köhler SJ, Tranvik LJ (2015) The relative influence of land cover, hydrology, and in-stream processing on the composition of dissolved organic matter in boreal streams. J Geophys Res Biogeosci 120:1491-1505

Kujawinski EB, Del Vecchio R, Blough NV, Klein GC, Marshall AG (2004) Probing molecular-level transformations of dissolved organic matter: insights on photochemical degradation and protozoan modification of DOM from electrospray ionization Fourier transform ion cyclotron resonance mass spectrometry. Mar Chem 92:23-37

Lakowicz JR (2006) Principles of fluorescence spectroscopy. Springer-Verlag, New York, NY

Lee S, Fuhrman JA (1987) Relationships between biovolume and biomass of naturally derived marine bacterioplankton. Appl Environ Microbiol 53:1298-1303

Levy S (2002) The antibiotic paradox: how the misuse of antibiotics destroys their curative powers, 2nd edn. Perseus Press, Cambridge, MA

Logue JB, Stedmon CA, Kellerman AM, Nielsen NJ and others (2016) Experimental insights into the importance of aquatic bacterial community composition to the degradation of dissolved organic matter. ISME J 10:533-545

*McKnight DM, Boyer EW, Westerhoff PK, Doran PT, Kulbe T, Andersen DT (2001) Spectrofluorometric characterization of dissolved organic matter for indication of precursor organic material and aromaticity. Limnol Oceanogr 46:38-48

* Middelboe M, Jørgensen NOG (2006) Viral lysis of bacteria: an important source of dissolved amino acids and cell wall compounds. J Mar Biol Assoc UK 86:605-612

* Murphy KR, Butler KD, Spencer RGM, Stedmon CA, Boehme JR, Aiken GR (2010) Measurement of dissolved organic matter fluorescence in aquatic environments: an inter laboratory comparison. Environ Sci Technol 44: 9405-9412

Murphy KR, Stedmon CA, Graeber D, Bro R (2013) Fluorescence spectroscopy and multi-way techniques. PARAFAC. Anal Methods 5:6557-6566

* Murphy KR, Stedmon CA, Wenig P, Bro R (2014) OpenFluoran online spectral library of auto-fluorescence by organic compounds in the environment. Anal Methods 6: 658-661

* Ohno T (2002) Fluorescence inner-filtering correction for determining the humification index of dissolved organic matter. Environ Sci Technol 36:742-746

*Papadimitriou EK (2010) Hydrolysis of organic matter during autoclaving of commingled household waste. Waste Manag 30:572-582

Peter H, Ylla I, Gudasz C, Romaní AM, Sabater S, Tranvik LJ (2011) Multifunctionality and diversity in bacterial biofilms. PLOS ONE 6:e23225

* Romaní AM, Guasch H, Muñoz I, Ruana J and others (2004) Biofilm structure and function and possible implications for riverine DOC dynamics. Microb Ecol 47:316-328

* Stedmon CA, Markager S (2005) Resolving the variability of dissolved organic matter fluorescence in a temperate estuary and its catchment using PARAFAC analysis. Limnol Oceanogr 50:686-697

* Stedmon CA, Markager S, Bro R (2003) Tracing dissolved organic matter in aquatic environments using a new approach to fluorescence spectroscopy. Mar Chem 82: 239-254

* Stedmon CA, Thomas DN, Granskog M, Kaartokallio H, Papadimitriou S, Kuosa H (2007) Characteristics of dissolved organic matter in Baltic coastal sea ice: allochthonous or autochthonous origins? Environ Sci Technol 41: 7273-7279

Sundaram S, Eisenhuth J, Howard G Jr, Brandwein H (2001) Retention of water-borne bacteria by membrane filters. Part I: Bacterial challenge tests on 0.2 and 0.22 micron rated filters. PDA J Pharm Sci Technol 55:65-86

Tranvik LJ, von Wachenfeldt E (2009) Interactions of dissolved organic matter and humic substances. In: Likens 
GE (ed) Encyclopedia of inland waters. Academic Press, Amsterdam, p 754-760

Tranvik LJ, Sherr EB, Sherr BF (1993) Uptake and utilization of 'colloidal DOM' by heterotrophic flagellates in seawater. Mar Ecol Prog Ser 92:301-309

Vybiral D, Denner EB, Haller CM, Busse HJ, Witte A, Hofle MG, Velimirov B (1999) Polyphasic classification of $0.2 \mu \mathrm{m}$

Editorial responsibility: Craig Carlson, Santa Barbara, California, USA filterable bacteria from the western Mediterranean Sea. Syst Appl Microbiol 22:635-646

* Walker SA, Amon RMW, Stedmon C, Duan S, Louchouarn P (2009) The use of PARAFAC modeling to trace terrestrial dissolved organic matter and fingerprint water masses in coastal Canadian Arctic surface waters. J Geophys Res Biogeosci 114:G00F06

Submitted: December 7, 2017; Accepted: September 20, 2018 Proofs received from author(s): November 29, 2018 